\title{
UPAYA PEMBERDAYAAN MASYARAKAT MELALUI DETEKSI DINI DAN PENGENDALIAN KESEHATAN REPRODUKSI DI DSN. TAWUN I, DS. TAWUN, KEC. KASREMAN WILAYAH KERJA PUSKESMAS KASREMAN KABUPATEN NGAWI
}

\section{Community Development Foreign Through The Detection Using Detection And Control of Reproduction Healthy In Tawun 1, Ds. Tawun, Puskesmas Kasreman Ngawi Regency}

\author{
Hamidatus Daris Sa'adah ${ }^{1}$, Rini Komalawati ${ }^{2}$, Agnes Mariasih $^{3}$ \\ Akademi Keperawatan Pemerintah Kabupaten Ngawi; Jl. Dr. Wahidin No 49 Ngawi \\ email:hamy.daries@gmail.com
}

\begin{abstract}
Abstrak
Latar Belakang: Premenopause adalah Fase terjadi pada usia 40 tahun dan dimulainya fase klimakterium. Fase ini timbul ditandai dengan siklus menstruasi menjadi tidak teratur, perdarahan menstruasi memanjang, jumlah darah menstruasi menjadi lebih banyak, dan adanya rasa nyeri saat menstruasi. Dampak secara fisik biologis yang dialami wanita pada sindrom premenopause adalah perasaan panas (hot flush), sakit kepala, cepat lelah, rematik, sakit pinggang, sesak napas, susah tidur, dan osteoporosis. Sedangkan untuk gejala psikologis adalah ingatan menurun, kecemasan, mudah tersinggung, setres dan depresi. Upaya pencegahan dan penanganan kejadian tersebut dapat dilakukan dengan tindakan deteksi dini reproduksi dan sebagai dasar dalam pengendalian permasalahan Pre Menopause. Tujuan: meningkatkan pengetahuan, kesadaran, kemampuan dan kemauan hidup sehat bagi setiap penduduk agar dapat mewujudkan derajat reproduksinya sendiri serta berperan aktif dalam mewujudkan kesehatan pre menopause. Metode: Pengabdian masyarakat yaitu pendidikan kesehatan meliputi ceramah atau penyuluhan, Tanya jawab, diskusi dan gambar tentang pengenalan dan tindak lanjut pre menopause di tatanan masyarakat. Hasil: Mayoritas masyarakat yang terlibat dalam pengabdian masyarakat ini adalah perempuan (72\%). Rerata usia wanita middle age $(59,74 \pm$ 6,5 ), wanita usia subur dengan normotensi sebanyak 57,4\%, Sebagian besar peserta penyuluhan kesehatan mempunyai sikap baik dalam menghadapi menopause, dengan tingkat pengetahuan baik. Kesimpulan: Deteksi dini reproduksi merupakan upaya dasar yang penting dilakukan dalam rangka pengendalian permasalahan reproduksi pada wanita. Upaya pengendalian ini dapat dimulai dengan pendidikan kesehatan untuk meningkatkan pemberian informasi tentang menopause megenai perubahan fisik yang dialami pada masa menopause dan ibu-ibu premenopause agar lebih siap menghadapi perubahan fisik yang terjadi. Gejala Premenopause adalah hal yang normal dialami oleh perempuan dan dapat melibatkan masyarakat dalam membantu ibu menghadapi gejala premenopause pada saat kegiatan masyarakat melalui tokoh masyarakat setempat.
\end{abstract}

Kata Kunci: Pre Menopause, Kesehatan Reproduksi, Pengabdian Masyarakat

\section{PENDAHULUAN}

Premenopause adalah Fase terjadi pada usia 40 tahun dan dimulainya fase klimakterium. Fase ini timbul ditandai dengan siklus menstruasi menjadi tidak teratur, perdarahan menstruasi memanjang, jumlah darah menstruasi menjadi lebih banyak, dan adanya rasa nyeri saat menstruasi (Mulyani, 2013).
Dampak secara fisik biologis yang dialami wanita pada sindrom premenopause adalah perasaan panas (hot flush), sakit kepala, cepat lelah, rematik, sakit pinggang, sesak napas, susah tidur, dan osteoporosis. Sedangkan untuk gejala psikologis adalah ingatan menurun, kecemasan, mudah tersinggung, setres dan depresi. Masalah yang timbul akibat menopause ini disebut dengan sindrom premenopause. Sindrom 
premenopause sering dihubungkan karena adanya kekhawatiran dalam menghadapi suatu situasi yang sebelumnya tidak pernah dikhawatirkan (Proverawati dan Sulistyawati, 2010).

Sindrom premenopause dialami oleh banyak wanita hampir diseluruh dunia, sekitar 70-80\% wanita Eropa, 60\% di Amerika, 57\% di Malaysia, $18 \%$ di Cina, dan $10 \%$ di Jepang, dan di Indonesia (Proverawati dan Sulistyawati, 2010).

Pengetahuan merupakan hasil dari tahu, dan ini terjadi setelah orang melakukan penginderaan terhadap suatu obyek tertentu (Notoatmojo, 2007). Pengetahuan mengenai menopause sangatlah diperlukan oleh wanita karena banyak wanita merasa takut mencapai masa menopause dan enggan membicarakan fase menopause, karena ada anggapan umum bahwa ini adalah pintu yang harus dilalui menuju masa tua. Dengan peningkatan pengetahuan pada wanita premenopause tentang menopause, diharapkan sikap wanita premenopause tentang menopause menjadi lebih baik (Proverawati dan Sulistyawati, 2010).

Hasil Survei menunjukkan bahwa perempuan dengan sindrom premenopause tidak bias menerima gejala-gejala yang ditandai dengan ciri-ciri sulit tidur, gelisah tanpa alasan, sering tersinggung dan tak mudah mengendalikan emosi.

Depresi dan stress merupakan beberapa dari gejala yang biasa dialami. Depresi dan stress menjadi mitos umum untuk wanita yang memasuki usia paruh baya sehingga mereka menganggap depresi merupakan hal yang normal untuk wanita usia 40-45 tahun. Depresi berat tidak boleh dilihat sebagai suatu kejadian yang biasa dan wanita yang menderita depresi pada masa tertentu dalam kehidupannya seharusnya menerima perhatian yang sama dengan penyakit lainnya (The Society of Obstetricians and Gynaecologist of Canada, 2006).

Upaya pencegahan kejadian tersebut dapat dilakukan dengan tindakan deteksi dini, berupa pemeriksaan kesehatan. Deteksi secara dini dapat dilakukan dengan pengecekan status gizi, tekanan darah, biokimia darah (khususnya glukosa darah, kolesterol, dan asam urat) secara rutin. Tentunya hasil pada saat deteksi dini dapat digunakan sebagai dasar pencegahan atau pengendalian masalah kesehatan.

\section{METODE}

Kegiatan ini merupakan bentuk kegiatan pengabdian kepada masyarakat dengan sasaran 120 wanita di Dusun Tawun, Desa Tawun Wilayah Puskesmas Kasreman. Rangkaian kegiatan ini dilakukan selama 1 bulan di Dusun Tawun, Desa Tawun Wilayah Puskesmas Kasreman Kabupaten Ngawi. Melaui kegiatan ini, diharapkan terjadi peningkatan pemahaman atau pengetahuan bagi wanita usia subur tentang deteksi dini dan pengendalian permasalahan pre menopause.

Pengabdian masyarakat ini terdiri dari 2 kegiatan utama. Kegiatan pertama adalah kegiatan pendidikan kesehatan bagi wanita usia subur tentang kesehatan reproduksi terutama permasalahan pre menopause. Di akhir kegiatan, dilakukan Kegiatan pengukuran tekanan darah, dilanjutkan dengan pemeriksaan gula darah, asam urat, dan kolesterol.

Instrumen yang digunakan dalam kegiatan pengabdian masyarakat ini adalah Lembar Balik, dan alat pengukuran tekanan darah yaitu tensimeter dan stetoskop. Alat lain yang digunakan yaitu alat pengukuran gula darah, asam urat dan kolesterol berupa alat ukur, tissue, lancet, dan pen lancet kapas alkhohol. Sedangkan alat penyuluhan kesehatan berupa sound system, LCD, dan leaflet.

HASIL

Mayoritas masyarakat yang terlibat dalam pengabdian masyarakat ini adalah perempuan $(72 \%)$. Rerata usia wanita middle age $(59,74 \pm 6,5)$, wanita usia subur dengan normotensi sebanyak 57,4\%, Sebagian besar peserta penyuluhan kesehatan mempunyai sikap baik dalam menghadapi menopause, dengan tingkat pengetahuan baik. Sebagian besar peserta penyuluhan kesehatan mempunyai sikap baik dalam menghadapi menopause, dengan tingkat pengetahuan baik.

\section{PEMBAHASAN}

Sebagian besar yang mengikuti kegiatan pengabdian masyarakat ini adalah wanita usia subur (72\%). Pengetahuan 
merupakan hasil dari tahu, dan ini terjadi setelah orang melakukan penginderaan terhadap suatu obyek tertentu. Penginderaan terjadi melalui panca indera manusia, yakni indera panglihatan, pendengaran, penciuman, rasa, dan raba. Sebagian besar pengetahuan manusia diperoleh melalui mata dan telinga dikutip dari Notoatmodjo (2003).

Hasil dari penyuluhan kesehatan bahwa sebagian besar ibu-ibu memiliki pengetahuan yaitu jika wanita memasuki masa menopause mengalami perubahan fisik seperti berkerutnya kulit didaerah wajah, leher, dan lengan, mudah tersinggung, mengalami kekeringan vagina, sulit tidur / insomnia, dan osteoporosis, ibu juga mengetahui menopause adalah fase dimana berhentinya menstruasi atau haid terakhir minimal 1 tahun. Sebagian besar ibu banyak mencari informasi tentang masa menopause melalui tenaga kesehatan.Dengan tingkat pengetahuan yang baik maka seseorang akan lebih banyak mengetahui perubahan yang terjadi menjelang menopause pada dirinya baik secara fisik maupun psikologis, sedangkan dengan pengetahuan yang kurang seseorang akan sulit mengenali tanda dan gejala yang terjadi menjelang menopause.

Sikap adalah suatu bentuk evaluasi atau reaksi terhadap suatu obyek, memihak atau tidak memihak yang merupakan keteraturan tertentu dalam hal perasaan (afeksi), pemikiran (kognitif) dan predisposisi tindakan (konasi) seseorang terhadap suatu aspek di lingkungan sekitarnya (Azwar. S, 2013). Hasil penyuluhan kesehatan bahwa ibu-ibu memiliki sikap yang baik dan cukup yang ditunjukkan bahwa sikap ibu dalam mengatasi keluhan saat menghadapi masa menopause yaitu, ibu sering melakukan kegiatan positif seperti olahraga, menerapkan gaya hidup sehat, serta menjaga pemenuhan nutrisi dengan cara mengkonsumsi sayuran dan vitamin, dan selalu mencari informasi yang berkaitan dengan menopause kepada tenaga kesehatan.

Kesiapan (readiness) adalah tingkat perkembangan dari kematangan atau kedewasaan yang menguntungkan dalam mempraktikkan sesuatu. Dapat juga diartikan sebagai keadaan siap siaga untuk mereaksikan atau menanggapi sesuatu. Kesiapan disini diartikan sebagai suatu keadaan ibu untuk mempersiapkan dirinya dalam menghadapi menopause, baik secara fisik maupun mental atau psikologisnya, yaitu siap menghadapi masa menopause dengan alasan karena masa menopause adalah hal yang alamiah yang dialami setiap wanita dimasa tua nantinya, semakin tua usia maka hormon akan mengalami penurunan dan daya seks juga berkurang, sehingga ibu mempersiapkan dirinya dalam menghadapi menopause baik secara fisik maupun secara psikologis. Sedangkan yang tidak siap beralasan karena belum siap menghadapi masa menopause yang menyebabkan ibu belum mempersiapkan dirinya dalam menghadapi menopause baik secara fisik maupun psikologis. Pengetahuan mengenai menopause yang perlu diketahui oleh wanita adalah mengenai apa itu menopause, faktorfaktor yang mempercepat atau memperlambat usia memasuki menopause dan terapi-terapi yang dapat digunakan dalam menghadapi menopause. Dengan peningkatan pengetahuan pada wanita premenopause tentang menopause, diharapkan kesiapan wanita premenopause dalam menghadapi masa menopause akan lebih baik (Proverawati dan Sulistyawati, 2010).

\section{SIMPULAN DAN SARAN}

Deteksi dini merupakan upaya dasar yang penting dilakukan dalam rangka pengendalian permasalahan pre menopause pada wanita. Upaya pengendalian ini dapat dimulai dengan pendidikan kesehatan untuk meningkatkan dalam memberikan informasi kesehatan tentang menopause pada ibu-ibu, mengenai perubahan fisik yang dialami, dan ibu-ibu pre menopause agar lebih siap mengahadapi perubahan fisik yang terjadi menjelang menopause. Gejala Premenopause adalah hal yang normal dialami oleh perempuan. Demikian juga untuk masyarakat dapat terlibat dalam membantu ibu menghadapi gejala premenopause pada saat kegiatan masyarakat melalui tokoh masyarakat setempat.

\section{UCAPAN TERIMAKASIH}

Ucapan terimakasih disampaikan kepada Kepala Desa Tawun, kepala dusun Dusun Tawun, ibu-ibu kader dan warga Desa 
Tawunr Wilayah Puskesmas Kasreman yang telah membantu kegiatan terlaksananya program pengabdian masyarakat.

\section{DAFTAR PUSTAKA}

Badan Penelitian dan Pengembangan Kesehatan Kementerian Kesehatan RI. 2013. Riset Kesehatan Dasar RISKESDAS 2013. Jakarta: Badan Penelitian dan Pengembangan Kesehatan Kementerian Kesehatan RI

Badan Penelitian dan Pengembangan Kesehatan Kementerian Kesehatan RI. 2014. Riset Kesehatan Dasar RISKESDAS 2014. Jakarta: Badan Penelitian dan Pengembangan Kesehatan Kementerian Kesehatan RI

Pusat Data dan Informasi Kementrian Kesehatan RI. 2017. Data dan Informasi (Profil Kesehatan Indonesia 2016). Jakarta: Pusat Data dan Informasi Kementrian Kesehatan RI

Proverawati, A danSulistyawati,E. 2010. Menopause danSindromePremenopause. Yogyakarta: Medical Book

Mulyani, S.N., 2013, Menopause Akhir Siklus Menstruasi pada Wanita di Usia Pertengahan, Nuha Media, Yogyakarta.

Proverawati, Atikah dan Sulistyawati, Emil, 2010, Menopause dan Sindrome Premenopause, Cetakan Pertama, Nuha Medika, Yogyakarta.

Rebecca \& Brown, 2006,Menopause,

Cetakan PT Gelora Aksara

Pratama, Erlangga, Jakarta
Manuaba, dkk. 2009. Mengalami Kesehatan Reproduksi Wanita. Jakarta: EGC

Mulyani, Nina Siti. 2013. Menopause. Yogyakarta: Medical Book

Nugroho, Taufan. 2014. Masalah Kesehatan Reproduksi Wanita. Yogyakarta: Medical Book

Notoatmodjo, S. 2007. Promosi Kesehatan dan Ilmu Perilaku.Jakarta: Rineka Cipta 